\title{
Heteroatom-Doped Carbon Nanostructures as Oxygen Reduction Reaction Catalysts in Acidic Media: An Overview
}

\author{
Kuldeep Mamtani • Umit S. Ozkan
}

Received: 26 October 2014/Accepted: 11 November 2014/Published online: 18 November 2014

(C) Springer Science+Business Media New York 2014

\begin{abstract}
This paper provides an overview of the studies that were conducted in our laboratories in the last decade on hetero-atom doped carbon structures as potential oxygen reduction reaction (ORR) catalysts for PEM fuel cells. These studies include evaluating the potential of nitrogen doped carbon nanostructures as cathode catalysts for proton exchange membrane and direct methanol fuel cells and examining the nature of the transition metal used as growth catalysts in synthesis of these materials, through activity and in situ and ex situ characterization experiments. These studies also shed some light on the ongoing debate about the differences and similarities between two classes of materials used for ORR, namely FeNC and $\mathrm{CN}_{\mathrm{x}}$ catalysts, through activity and stability tests, X-ray absorption spectroscopy, X-ray photoelectron spectroscopy, Mössbauer spectroscopy, temperature-programmed techniques and selective poisoning experiments designed to probe the active sites.
\end{abstract}

Keywords Oxygen reduction reaction $\cdot \mathrm{CN}_{\mathrm{x}} \cdot \mathrm{FeNC}$

\section{Introduction}

Recent decade has seen an increased interest in proton exchange membrane (PEM) fuel cells as efficient energy conversion devices for mobile applications. In spite of the significant advances made in all components of PEM fuel cells, the high cost associated with the Pt-based cathode electrocatalysts continues to impede their wide-spread

K. Mamtani · U. S. Ozkan $(\bowtie)$

Department of Chemical and Biomolecular Engineering, The

Ohio State University, Columbus, OH, USA

e-mail: ozkan.1@osu.edu application. The reaction that takes place in the cathode is the oxygen reduction reaction (ORR). While complete reduction of oxygen to water involves transfer of four electrons per oxygen molecule, partial reduction to $\mathrm{H}_{2} \mathrm{O}_{2}$, which involves transfer of two electrons, could also occur, resulting in power loss as well as leading to material deterioration.

$\mathrm{O}_{2}+4 \mathrm{H}^{+}+4 \mathrm{e}^{-} \rightarrow 2 \mathrm{H}_{2} \mathrm{O}$

$\mathrm{O}_{2}+2 \mathrm{H}^{+}+2 \mathrm{e}^{-} \rightarrow 2 \mathrm{H}_{2} \mathrm{O}_{2}$

Since the operating temperature for PEM fuel cells is relatively low $\left(\sim 80^{\circ} \mathrm{C}\right)$, the oxygen reduction reaction suffers from slow kinetics, hence requiring high loading levels of Pt.

There have been prior studies seeking alternatives to $\mathrm{Pt}$ for PEM fuel cells, as summarized in several recent reviews [1-4]. Some of these studies were based on the nature-inspired concept of using hemoglobin-type molecules $\left(\mathrm{N}_{4}\right.$-chelates with $\mathrm{Co}$ or $\mathrm{Fe}$ ions as the active center) to perform the oxygen reduction function [5, 6]. Large organic macrocycles containing $\mathrm{Fe}$ or Co centers such as phtalocyanine were reported to be active for ORR when supported on high-surface area carbon [7]. Although these complex compounds were not stable for long periods of time in the fuel cell environment, it was discovered that subjecting them to a heat treatment could improve their stability and activity. Van Veen et al. were one of the earlier groups to report the formation of a new catalytic site upon high temperature treatments of carbon-supported organo-metallic macrocycles [8]. Later studies have reported that it was not necessary to begin with organic macrocycles in order to produce active and stable nonnoble metal ORR electrocatalysts [9]. Often heating an $\mathrm{N}$ and $\mathrm{C}$ source over metal particles was sufficient. 
Dodelet and co-workers have conducted extensive studies on the preparation of ORR catalysts from simple Fe and nitrogen precursors [10-13]. They have proposed an active site, where $\mathrm{Fe}$ is stabilized by at least two pyridinic nitrogens in a manner similar to a phenanthroline molecule adsorbing an iron ion. Their more recent studies reported activities approaching that of Pt catalysts [14].

While there have been reports pointing to a N-stabilized metal center as the active site, there have been other studies which suggested that the metal used in the formation of the carbon nano-structures simply serves as a growth catalyst during the pyrolysis and is not a part of the active site [15$18]$.

\section{Nitrogen-Containing Carbon Nanostructures $\left(\mathrm{CN}_{\mathbf{x}}\right)$ as ORR Electrocatalysts}

In the early phase of our studies, catalyst samples were prepared by decomposing $\mathrm{C}$ - and $\mathrm{N}$-containing precursors (e.g., $\mathrm{CH}_{3} \mathrm{CN}$ ) over Vulcan carbon (VC) in an inert atmosphere at temperatures ranging from 600 to $900{ }^{\circ} \mathrm{C}$. Some of the VC supports were "doped" with Fe (or Ni) prior to pyrolysis using an acetate or nitrate precursor of the metal. The pyrolysis was monitored using a thermogravimetry/differential scanning calorimetry technique combined with on-line mass spectrometry. The samples were observed to "gain weight" as a result of C deposition on the surface. When these post-pyrolysis samples were characterized using temperature programmed oxidation (TPO), the VC which went through pyrolysis was seen to have a lower onset temperature for oxidation, compared to untreated VC. Also seen in these TPO experiments was the presence of a strong $\mathrm{NO}_{\mathrm{x}}$ signal over post-pyrolysis $\mathrm{VC}$ sample, clearly showing the presence of significant levels of nitrogen in these materials [16]. When these materials were characterized using the XPS, N1s region of the spectra clearly showed the existence of various nitrogen species associated with the graphene structure (Fig. 1).

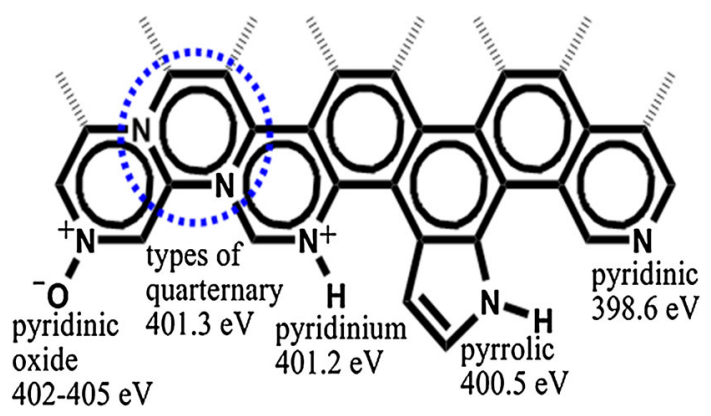

Fig. 1 Types of nitrogen species that can be incorporated into graphitic carbon and their N $1 \mathrm{~s}$ XPS binding energies
Activity improvement observed over undoped VC following $\mathrm{CH}_{3} \mathrm{CN}$ pyrolysis suggested that ORR activity can be achieved without a metal center, however, because of the presence of metal impurities in VC, a question still remained as to the source of activity. To answer this question, a pure alumina support was prepared using a solgel technique, taking great care to eliminate any metal contamination. For comparison, samples were also synthesized using alumina support doped with $\mathrm{Fe}$ or $\mathrm{Ni}$.

Following $\mathrm{CH}_{3} \mathrm{CN}$ pyrolysis, significant levels of carbon deposition were observed on all substrates, with or without metal doping. Samples were washed with HF to remove the alumina support as well as any exposed metal and the washed samples were characterized extensively. $\mathrm{CN}_{\mathrm{x}}$ catalysts grown over $\mathrm{Fe}-\mathrm{Al}_{2} \mathrm{O}_{3}$ support still had the highest ORR activity. However, there was also significant activity over the $\mathrm{CN}_{\mathrm{x}}$ catalysts grown over alumina support with no metal doping. This result was significant in showing that ORR activity can be achieved without a metal center $[17,18]$.

X-ray photoelectron spectroscopy (XPS) spectra and ORR activity measurements taken over these samples showed a correlation between the pyridinic $\mathrm{N}$ content and enhanced ORR activity (Fig. 2) [17]. Catalysts with a higher pyridinic-N content were more active.

When the nano-structure of these $\mathrm{CN}_{\mathrm{x}}$ materials were examined using high-resolution transmission electron microscopy (TEM), significant differences in the nanogeometries were observed, ranging from nano-onions to stacked-platelets. What was different about these nanogeometries was the way different crystal planes were exposed [16]. Figure 3 shows examples of carbon nanostructures prepared in our laboratories. Herring-bone and stacked cup structures prepared over Fe-containing substrates by pyrolyzing a $\mathrm{C}-\mathrm{N}$ source $\left(\mathrm{CH}_{3} \mathrm{CN}\right)$ had more edge plane exposure and had higher activity. Pyridinic $\mathrm{N}$ content was also higher in nano-geometries preferentially exposing edge planes. Multi-walled nano-tubes with graphene planes parallel to the axis of the fiber and hence exposing only the basal planes had much lower activity. Also, noted in these studies was the fact that edge planes with no nitrogen content had no ORR activity. Stacked platelet structure which was prepared without any nitrogen source had very little activity although it had mostly edge plane exposure (Fig. 3d) [19].

$\mathrm{CN}_{\mathrm{x}}$ samples grown over Fe-containing supports were further characterized by Mössbauer spectroscopy (Fig. 4). Mössbauer spectroscopy results were important in providing additional insight into the role of iron. Prior to washing, cementite was the primary iron phase and it increased with the time of the acetonitrile pyrolysis, verifying that the fiber growth was taking place through a carbide intermediate. The low temperature $(77 \mathrm{~K})$ spectrum showed the nature of the metallic iron as a paramagnetic phase $(\gamma-\mathrm{Fe})$, 


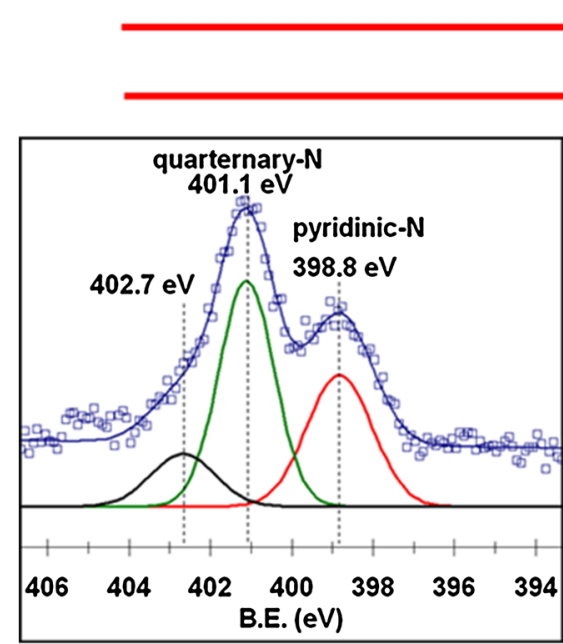

(a)

\section{Increasing pyridinic nitrogen content Increasing ORR activity}

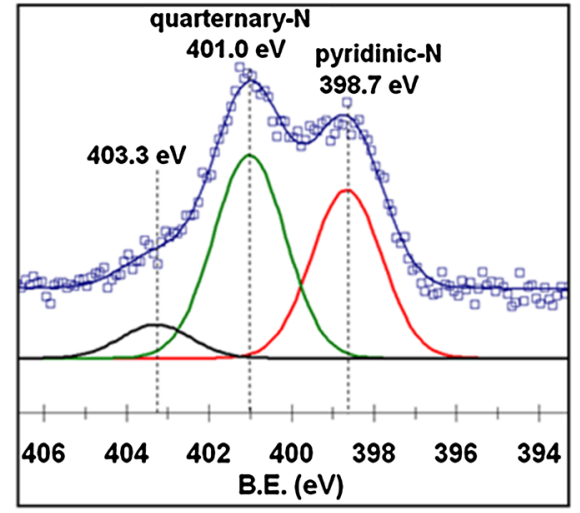

(b)

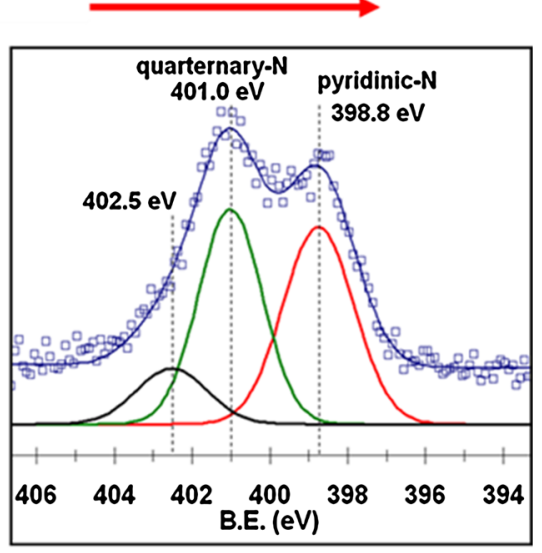

(c)

Fig. 2 XPS spectra of $\mathrm{CN}_{\mathrm{x}}$ catalysts grown over different substrates a $\mathrm{CN}_{\mathrm{x}}: \mathrm{Ni} / \mathrm{Al}_{2} \mathrm{O}_{3}, \mathbf{b} \mathrm{CN}_{\mathrm{x}}: \mathrm{Al}_{2} \mathrm{O}_{3}$ only, $\mathbf{c} \mathrm{CN}_{\mathrm{x}}: \mathrm{Fe} / \mathrm{Al}_{2} \mathrm{O}_{3}$. Spectra are taken after HF washing

(a)

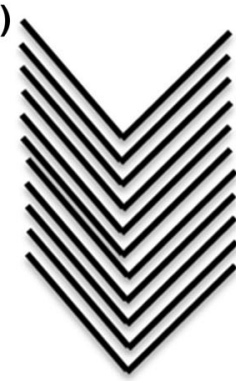

(c)

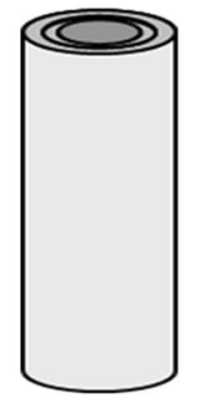

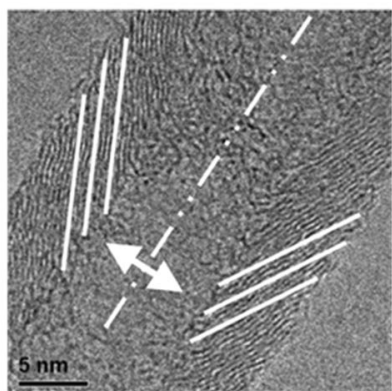

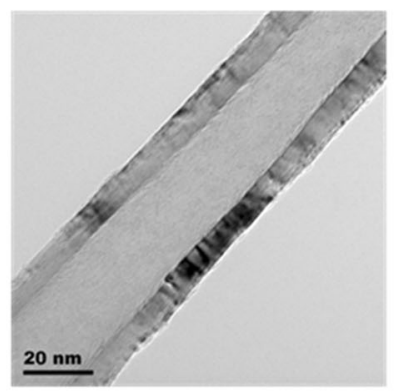

(b)
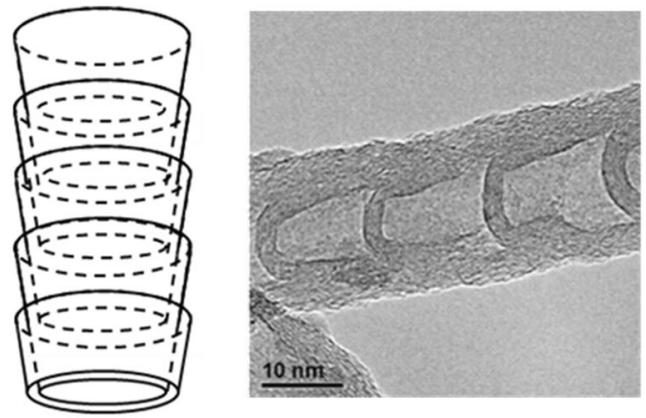

(d)
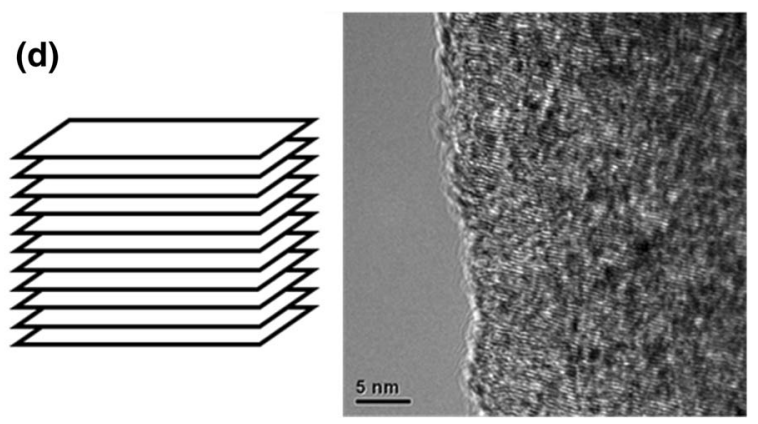

Fig. 3 Carbon nano structures and corresponding TEM images of materials synthesized in our laboratories. a Herring-bone, b stacked cup, c multi-walled nano-tube, $\mathbf{d}$ stacked platelet

verifying that the iron particles left in the samples after washing were encased in graphite, as seen in the insets. There was no evidence of a $\mathrm{N}$-stabilized $\mathrm{Fe}$ center or any correlation of activity with a $\mathrm{Fe}$ phase, providing further support that $\mathrm{Fe}$ may not be needed for the ORR reaction [20].

In addition to alumina support, catalysts could also be prepared using $\mathrm{SiO}_{2^{-}}$and $\mathrm{MgO}$-supported metal particles as growth catalysts $[15,21]$. Using these supports is a more attractive option because they can be removed from carbon using safer leaching agents.

\section{In Situ Characterization of the Pyrolytic Growth of $\mathbf{C N}_{\mathbf{x}}$ Catalysts}

The growth process of nitrogen-doped carbon nano-structures $\left(\mathrm{CN}_{\mathrm{x}}\right)$ was characterized using in situ [X-ray 
absorption near edge structure (XANES), extended X-ray absorption fine structure (EXAFS), and X-ray diffraction (XRD)] and ex situ (XPS, TEM) techniques [22]. $\mathrm{CN}_{\mathrm{x}}$ nano-structures were grown on two different Co-doped substrates: $\mathrm{VC}$ and $\mathrm{MgO} . \mathrm{CN}_{\mathrm{x}}$ formation was achieved by pyrolyzing a $\mathrm{C}$ - and $\mathrm{N}$-containing compound, $\mathrm{CH}_{3} \mathrm{CN}$, at high temperatures.

Figure 5 shows the in situ XANES spectra of the Co/VC and $\mathrm{Co} / \mathrm{MgO}$ growth substrates during the $\mathrm{CH}_{3} \mathrm{CN}$

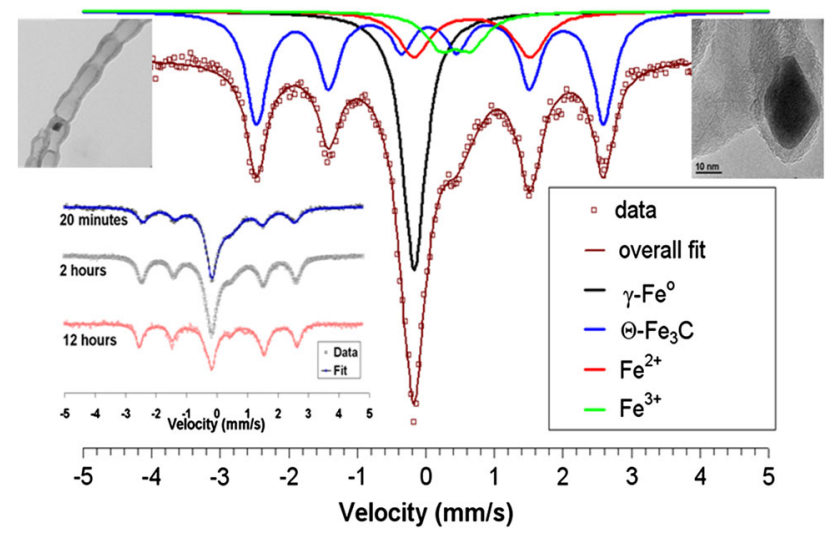

Fig. 4 Mössbauer spectra of $\mathrm{CN}_{\mathrm{x}}$ grown over $\mathrm{Fe} / \mathrm{Al}_{2} \mathrm{O}_{3}$ before washing. Inset effect of pyrolysis time; TEM images showing $\mathrm{Fe}$ particles encased in the carbon structure pyrolysis. The Co phase was seen to go through different transformations during the pyrolysis process, depending on the growth substrate used. The Co species, which started in an acetate matrix prior to pyrolysis, became partially reduced with heating and with $\mathrm{CH}_{3} \mathrm{CN}$ treatment. Co supported on $\mathrm{VC}$ was more reduced at the end of the pyrolysis step. After washing the samples in acid, XRD, $\mathrm{X}$-ray absorption spectroscopy (XAS), and XPS analysis showed the Co phase left behind to be primarily metallic, regardless of the growth substrate used. Figure 6 shows the XANES and magnitudes of $k^{2}$-weighted Fourier transforms of Co K-edge EXAFS spectra. Although the metal may be in different oxidation states over the two substrates at the end of the pyrolysis process, after acid washing, only metal remaining in these samples is encased in carbon and is very similar regardless of the support used. TEM imaging showed $\mathrm{CN}_{\mathrm{x}}$ after acid-washing to be in the form of stacked cup nano-structures, with metallic cobalt particles visibly encased in carbon. The nitrogen content and the types of $\mathrm{N}$ species were significantly different on the two substrates, which led to activity differences as shown by $\mathrm{RDE}$. Those grown on $\mathrm{Co}-\mathrm{MgO}$ had a higher nitrogen content, as well as a higher fraction of pyridinic $\mathrm{N}$ and oxidized pyridinic $\mathrm{N}$ compared to their counterparts grown on Co-VC. This difference also manifested itself in the superior performance of the former, while acid washing led
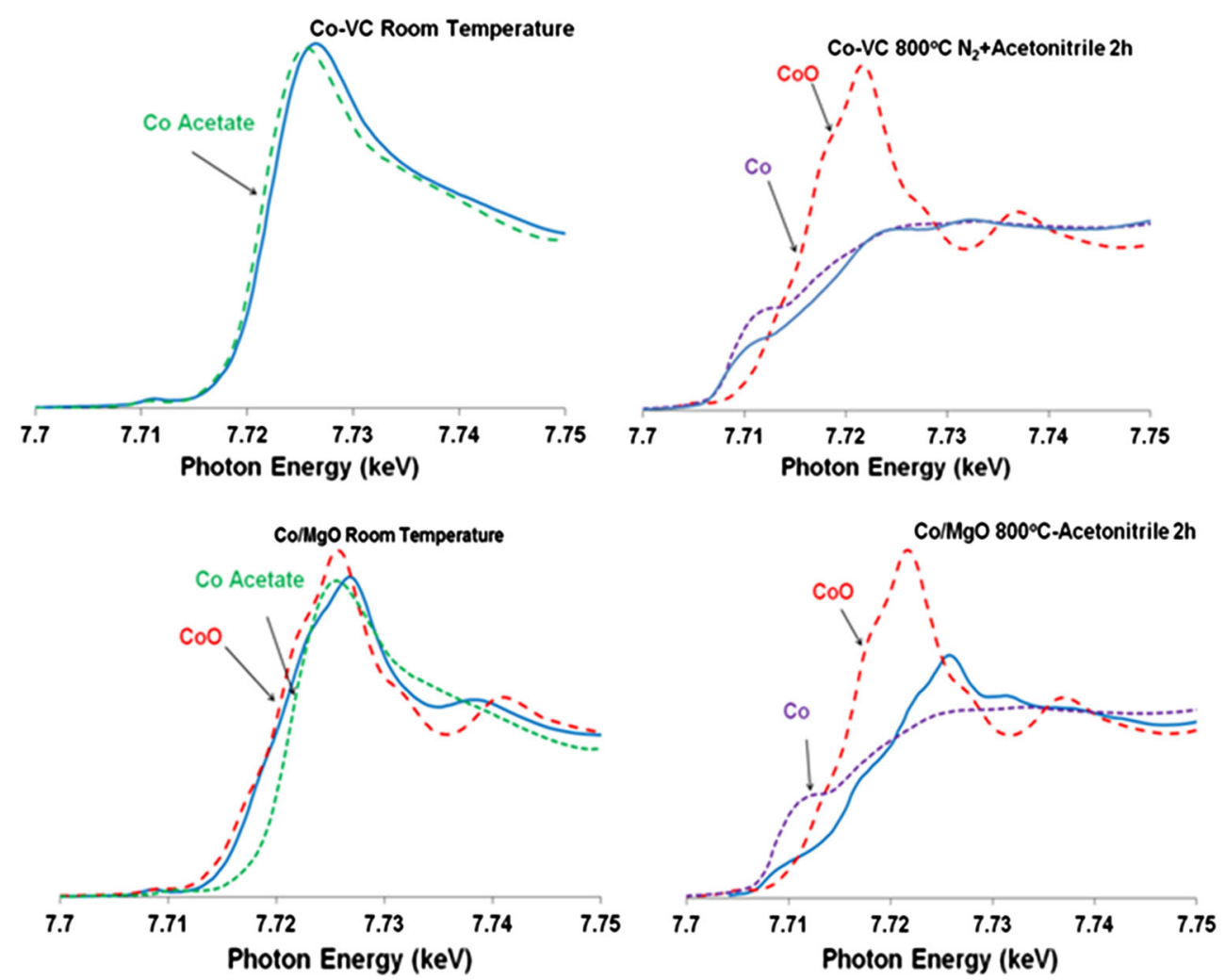

Fig. 5 Normalized in situ XANES spectra of Co K-edge during the pyrolytic growth of $\mathrm{CN}_{\mathrm{x}}$ over $\mathrm{Co} / \mathrm{VC}$ and $\mathrm{Co} / \mathrm{MgO}$ substrates at the beginning and at the end of the pyrolysis process 

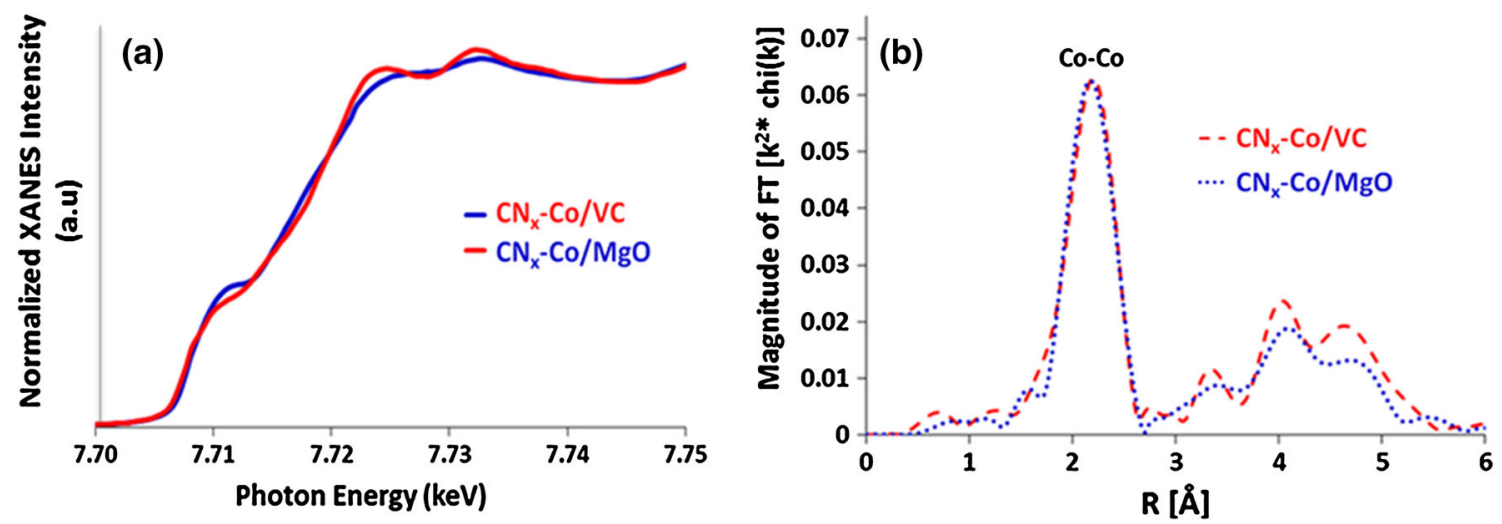

Fig. 6 XAFS characterization of $\mathrm{CN}_{\mathrm{x}}$ grown on $\mathrm{Co} / \mathrm{VC}$ and $\mathrm{Co} / \mathrm{MgO}$ substrates, a normalized XANES spectra of Co $\mathrm{K}$-edge, $\mathbf{b}$ magnitudes of $k^{2}$-weighted Fourier transforms of Co K-edge EXAFS spectra. Spectra are acquired after acid washing

to improved performance for both. These results were consistent with previous findings that showed a correlation between the pyridinic $\mathrm{N}$ content and ORR activity, regardless of how the $\mathrm{CN}_{\mathrm{x}}$ nano-structures were grown.

\section{$4 \mathbf{C N}_{\mathbf{x}}$ Catalysts as Potential Direct Methanol Fuel Cell Catalysts}

Direct methanol fuel cells (DMFCs) utilize a direct feed of aqueous methanol to the anode in place of the hydrogen in a PEM fuel cell. Replacing hydrogen with aqueous methanol removes the need for fuel reformation and hydrogen storage, therefore, greatly simplifying the inlet balance-ofplant for fuel cell systems.

In DMFC the anode and cathode reactions are the following:

$$
\begin{aligned}
& \mathrm{CH}_{3} \mathrm{OH}+\mathrm{H}_{2} \mathrm{O} \rightarrow \mathrm{CO}_{2}+6 \mathrm{H}^{+}+6 \mathrm{e}^{-} \\
& 3 / 2 \mathrm{O}_{2}+6 \mathrm{H}^{+}+6 \mathrm{e}^{-} \rightarrow 3 \mathrm{H}_{2} \mathrm{O}
\end{aligned}
$$

While DMFCs have advantages in fuel supply and storage, methanol crossover limits the technology currently. Ptbased catalysts are active for methanol oxidation and also suffer from ORR activity loss in the presence of methanol, which poses a serious problem for direct methanol fuel cells (DMFC), where the membrane is not impermeable for methanol. Methanol crossover, where the methanol fed to the anode permeates through the membrane to the cathode side, inhibits the Pt-based cathode catalysts and causes a reduction in the fuel cell coulombic efficiency [23]. The methanol oxidation reaction (MOR) occurs at the cathode as a parasitic reaction, reducing the open circuit potential [24]. There is also a potential for the methanol and MOR intermediates and products to poison the cathode catalyst [25].

An important result from our studies was related to the inactivity of the nitrogen-containing carbon structures for methanol oxidation [26]. When $\mathrm{CN}_{\mathrm{x}}$ catalysts were tested in the presence of methanol they showed no activity loss for ORR and they showed no activity for methanol oxidation, rendering them attractive candidates for DMFC or Mixed Reactant DMFCs. Figure 7 presents a voltammogram that shows that there is no methanol oxidation activity and there is no activity loss due to methanol in these catalysts, as opposed to $\mathrm{Pt} / \mathrm{VC}$ which shows very significant methanol oxidation [26].

\subsection{Carbon Corrosion Characteristics of $\mathrm{CN}_{\mathrm{x}}$ Catalysts}

The oxidizing and acidic environment of PEM and DMFC cathodes provides an additional challenge in the development of catalyst materials. The long-term stability of the carbon black in the cathode remains a concern. Efforts have been made to create new ORR catalysts using conductive supports with better corrosion resistance. Researchers have been studying the corrosion properties of cathode materials including supports of carbon blacks and carbon nanostructures using accelerated half-cell testing [27,28] in addition to extended time-on-stream full fuel cell testing. The electrochemical hyrdoquinone/quinone redox pair is indicative of the oxidation of carbonaceous material (Fig. 8a). $\mathrm{CN}_{\mathrm{x}}$ catalysts and VC were compared in accelerated aging conditions using hydroquinone/quinone cyclic voltammetry. Figure $8 \mathrm{~b}$ shows the intermittent CVs taken over VC while performing chronoamperometric potential holds. The hydroquinone/quinone peaks are evident by the increase in current at $\sim 0.6 \mathrm{~V}$ vs. NHE $[27,29]$ with time in the anodic (upper) set of linear scans. The intensity of the peaks increases significantly as the duration of high-voltage hold increases. Figure $8 \mathrm{c}$ shows similar $\mathrm{CVs}$ taken over $\mathrm{CN}_{\mathrm{x}}$. The intensity increase of hydroquinone/quinone peaks in $\mathrm{CN}_{\mathrm{x}}$ materials is smaller than $\mathrm{VC}$, suggesting that these materials are more corrosion resistant [30]. 


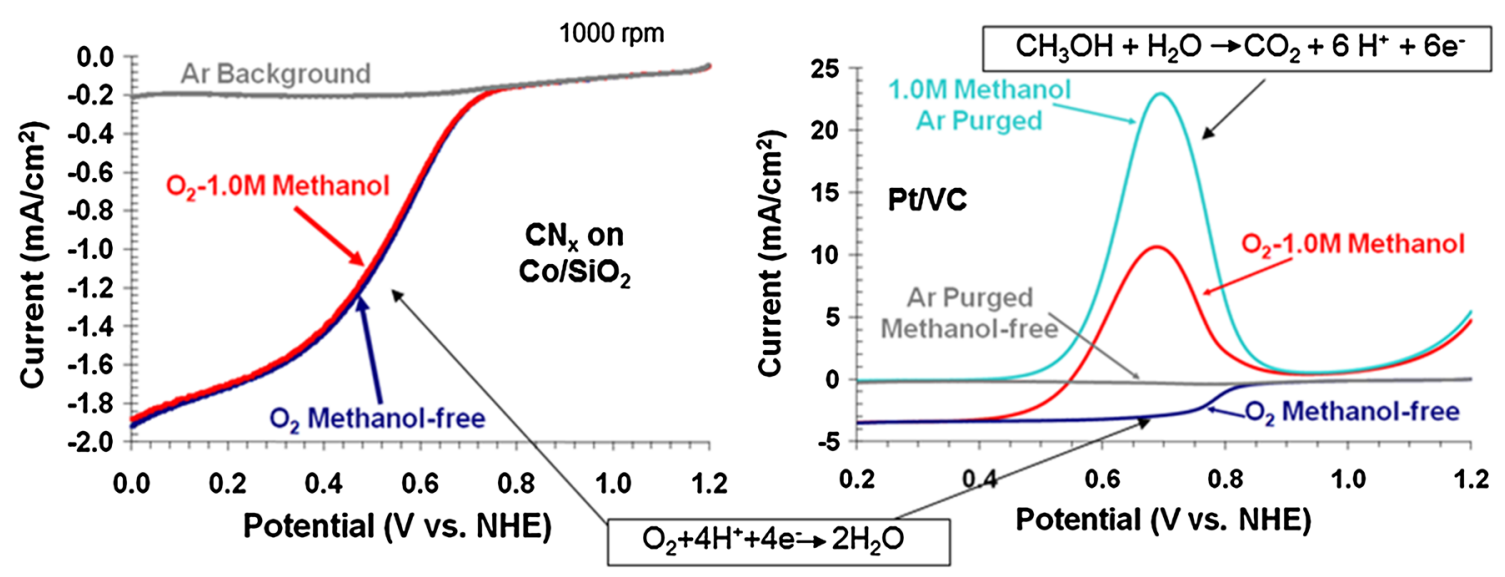

Fig. 7 Reduction sweep voltammograms for $\mathrm{CN}_{\mathrm{x}}$ and $\mathrm{Pt} / \mathrm{VC}$ in $0.5 \mathrm{M} \mathrm{H} 2 \mathrm{SO} 4$ solution at $1,000 \mathrm{rpm}$ showing both $1.0 \mathrm{M}$ methanol and methanol-free systems
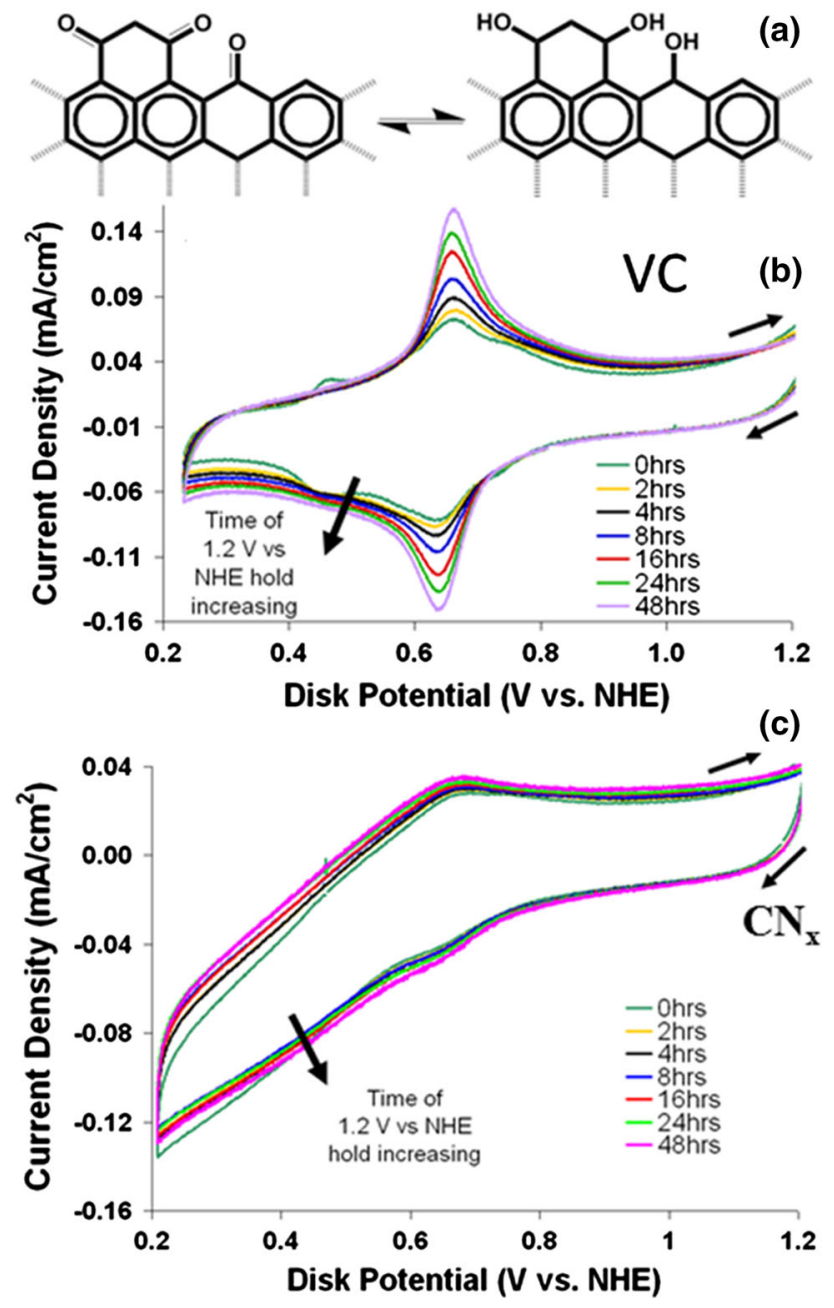

Fig. 8 a Electrochemically active hydroquinone (right)-quinone (left) reduction-oxidation couple on graphite edge. Evolution of the hydroquinone/quinone species on $\mathbf{b} \mathrm{VC}, \mathbf{c} \mathrm{CN}_{\mathrm{x}}$. CVs are taken after 0 , $2,4,8,16,24,48 \mathrm{~h}$ with $1.2 \mathrm{~V}$ vs. NHE potential hold in $0.5 \mathrm{M}$ $\mathrm{H}_{2} \mathrm{SO}_{4}$

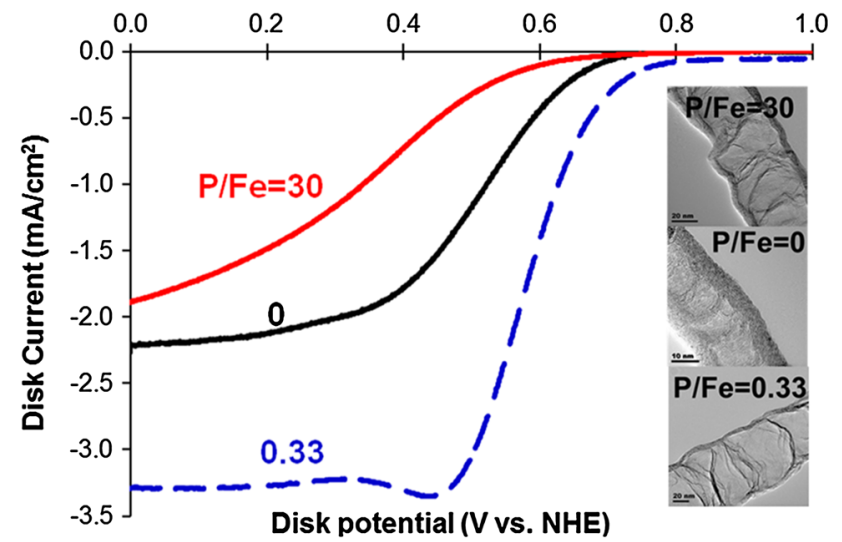

Fig. 9 Effect of $\mathrm{P} / \mathrm{Fe}$ ratio used in the growth substrate on ORR activity of $\mathrm{CN}_{\mathrm{x}}$ catalysts. Inset TEM images of catalyst nanostructures

\section{Incorporation of Other Heteroatoms}

The inclusion of noncarbon atoms (nitrogen, sulfur, phosphorus, etc.) into the hexagonal networks of graphitic carbons is believed to modify the electronic and chemical properties carbon [31]. In previous studies, phosphorous incorporation into carbon-nitrogen nanostructure lattice was reported [31], although the ORR catalytic activity of these structures was not studied. Phosphorus and sulfur, like nitrogen, can impart graphitic carbon catalysts with increased electron donation ability. It is a natural extension that the inclusion of heteroatoms into graphitic, ORR electrocatalysts would alter the reaction properties. $\mathrm{CN}_{\mathrm{x}} \mathrm{P}_{\mathrm{y}}$ catalysts were synthesized by pyrolyzing acetonitrile at $900{ }^{\circ} \mathrm{C}$ over a magnesia support doped with iron acetate and triphenylphosphine. When $\mathrm{Fe} / \mathrm{P}$ ratios were changed, significant differences were observed in the ORR activity measured by rotating disk electrode [32]. Figure 9 shows a comparison of the ORR activities between $\mathrm{CN}_{\mathrm{x}}$ and $\mathrm{CN}_{\mathrm{x}} \mathrm{Py}$ catalysts. 
Catalysts grown over $\mathrm{Fe} / \mathrm{MgO}$ substrate doped with small amounts of phosphorous $(\mathrm{P} / \mathrm{Fe}<1)$ showed significant activity improvement compared to P-free sample as seen by the higher onset potential. However, the samples grown over much higher $\mathrm{P} / \mathrm{Fe}$ ratios showed the opposite effect, suggesting that there is an optimum level of $\mathrm{P}$ doping to be used in the growth of these materials. We have also observed increased disorder in the nanofiber morphology with $\mathrm{P}$ doping (Fig. 9, inset). It is not clear how the P-doping changes the ORR activity. Low levels of phosphorous are thought to lower the eutectic point of transition metals used to grow carbon nanostructure during pyrolysis, which can impact the carbon growth process $[31,33]$.

When density functional theory (DFT), as implemented in the Gaussian 03 program, 6 was employed to investigate the capability of edge $\mathrm{P}$ to catalyze the ORR, the computational investigation demonstrated that an edge phosphinate group can be active for 2- and 4-electron ORR in a PEM fuel cell [34].

Effect of $\mathrm{S}$ was also examined using thiophene in the pyrolysis gas mixture. Sulfur was found to serve as a growth promoter, with no detrimental effect on activity [35].

\section{Active Site Debate}

Although our studies consistently suggested that the metal $(\mathrm{Fe}, \mathrm{Co})$ used as growth substrate during the pyrolysis process served only as a catalyst for the formation of the carbon nanostructures, and after leaching, the only metal left was completely encased in carbon, there has been continuing debate about the nature of active site and the role of the metal in the $\mathrm{CN}_{\mathrm{x}}$ materials. In an effort to clarify some of the ambiguity, we embarked upon a series of studies to use selective poisons to probe the active site. The rationale was that, if Fe centers were indeed the active site, the use of known poisons for iron catalysts should lead to significant activity loss in ORR.

\subsection{Use of CO Poisoning as a Probe}

In this study, interaction of carbon monoxide with $\mathrm{CN}_{\mathrm{x}}$ catalysts was investigated using pulse chemisorption, DRIFTS, and cyclic voltammetry techniques [36].

Cyclic voltammograms in electrolytes saturated with argon, carbon monoxide, and oxygen were acquired at $0 \mathrm{rpm}$. Similar experiments were conducted with $\mathrm{Pt} / \mathrm{VC}$ catalyst for comparison (Fig. 10). The catalyst-coated electrodes were not subjected to any additional treatments. Over the $\mathrm{Pt} / \mathrm{VC}$ catalyst, carbon monoxide is seen to oxidize, as evidenced by the peak at $0.9 \mathrm{~V}$ vs. NHE on the anodic scan in CO-saturated electrolyte (Fig. 10a). Furthermore, the decrease in the current density in $\mathrm{CO}$ over the $\mathrm{Pt} / \mathrm{VC}$ catalyst
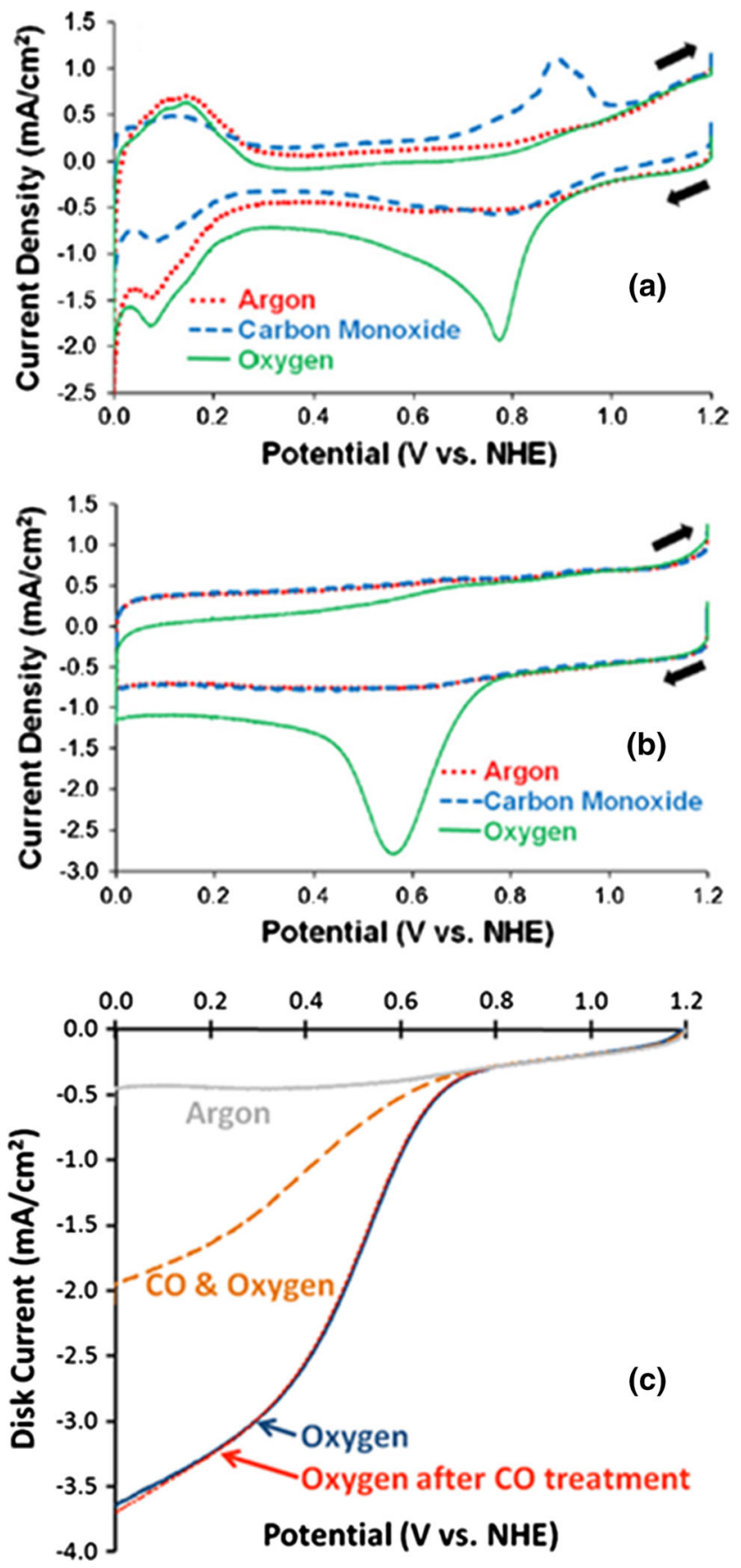

Fig. 10 a, b RDE cyclic voltammograms in $0.5 \mathrm{M} \mathrm{H}_{2} \mathrm{SO}_{4}$ saturated with argon, $\mathrm{CO}$, and $\mathrm{O}_{2}(0 \mathrm{rpm})$ for $\mathrm{Pt} / \mathrm{VC}$ and $\mathrm{CN}_{\mathrm{x}}$. $\mathbf{c} \mathrm{RDE}$ cathodic scans for $\mathrm{CN}_{\mathrm{x}}$ in $0.5 \mathrm{M} \mathrm{H}_{2} \mathrm{SO}_{4}$ electrolyte saturated with argon, $\mathrm{O}_{2}$, $\mathrm{CO}+\mathrm{O}_{2}$, and $\mathrm{O}_{2}$ after $\mathrm{CO}$ treatment $(1,000 \mathrm{rpm})$

compared to argon-saturated electrolyte corresponds to a decrease in the $\mathrm{H}^{+}$adsorption and desorption (potential range of $0.2-0.0 \mathrm{~V}$ vs. NHE), showing a clear poisoning effect. This suggests that proton adsorption is restricted by carbon monoxide adsorbed on the platinum sites. The CVs obtained over the $\mathrm{CN}_{\mathrm{x}}$ catalyst, however, are identical regardless of whether the electrolyte is saturated with argon 
or $\mathrm{CO}$, clearly showing that there is no electrochemical interaction of $\mathrm{CO}$ with any site over this catalyst (Fig. 10b).

The RDE cathodic potential scans taken over $\mathrm{CN}_{\mathrm{x}}$ catalysts in electrolytes saturated with different gases or gas mixtures, namely, Ar, $\mathrm{O}_{2}, \mathrm{O}_{2}+\mathrm{CO}$, and $\mathrm{O}_{2}$ after $\mathrm{CO}$ treatment are shown in Fig. 10c. As expected, when the electrolyte is saturated with a mixture of $\mathrm{CO}$ and $\mathrm{O}_{2}$ (50:50), the current density drops by about one half of that observed in pure oxygen. When the scan is repeated in pure oxygen following $\mathrm{CO}$ treatment, there is no difference in the disk currents obtained before or after $\mathrm{CO}$ treatment indicating that $\mathrm{CN}_{\mathrm{x}}$ catalysts did not suffer from poisoning with CO. Similar results were observed in chronoamperometric experiments where $\mathrm{CN}_{\mathrm{x}}$ catalysts exhibited only a dilution effect when oxygen was replaced with a 50:50 mixture of oxygen and argon or oxygen and $\mathrm{CO}$ unlike Pt/ VC sample, which showed a complete loss of activity.

In addition, pulsed chemisorption experiments at $35{ }^{\circ} \mathrm{C}$ were performed using carbon monoxide as the adsorbate. There was no $\mathrm{CO}$ uptake over $\mathrm{CN}_{\mathrm{x}}$ whereas $\mathrm{Pt} / \mathrm{VC}$ showed significant $\mathrm{CO}$ adsorption. There was also $\mathrm{CO}_{2}$ formation observed as a result of interaction of $\mathrm{CO}$ with the Pt sites, which may suggest a possible contribution from Boudouard reaction. The interaction of $\mathrm{CO}$ with the catalyst surface was also examined through DRIFT spectroscopy. Following $\mathrm{CO}$ adsorption, when the gas stream is switched to $\mathrm{He}$, bands at $2165,2115,2060$ and $1768 \mathrm{~cm}^{-1}$ are observed over the $\mathrm{Pt} / \mathrm{VC}$ catalyst, suggesting strong interaction of $\mathrm{CO}$ with the $\mathrm{Pt}$ sites. When a similar experiment was performed over $\mathrm{CN}_{\mathrm{x}}$, no adsorbed $\mathrm{CO}$ species were observed after the gas stream was switched to He [36].

\subsection{Use of Cyanide Poisoning as a Probe}

To further probe the active sites, additional poisoning experiments were conducted using cyanide $(\mathrm{KCN})$ as a poison. The motivation for these studies was a report in the literature that pyrolyzed and unpyrolyzed iron pthalocyanine catalysts showed significant poisoning by cyanide [37]. The conclusion of the report was that the significant decrease observed in ORR onset potential of these catalysts in the presence of cyanide would suggest that the active sites in these materials are Fe-centered.

Figure $11 \mathrm{a}, \mathrm{b}$ shows the RDE measurements performed in a phosphate buffer of $\mathrm{pH} 6$ over $\mathrm{Pt} / \mathrm{VC}$ and $\mathrm{CN}_{\mathrm{x}}$, respectively, to examine the effect of cyanide in their ORR activity. Scans taken in the absence and presence of cyanide are presented in the same figures. The $\mathrm{Pt} / \mathrm{VC}$ catalyst shows a clear poisoning effect, with a decrease in onset potential over $450 \mathrm{mV}$. The significant decrease in limiting current suggests a loss of Pt sites. Interestingly, there is no poisoning effect observed for the $\mathrm{CN}_{\mathrm{x}}$ catalysts in the presence of cyanide. The onset potential and the current
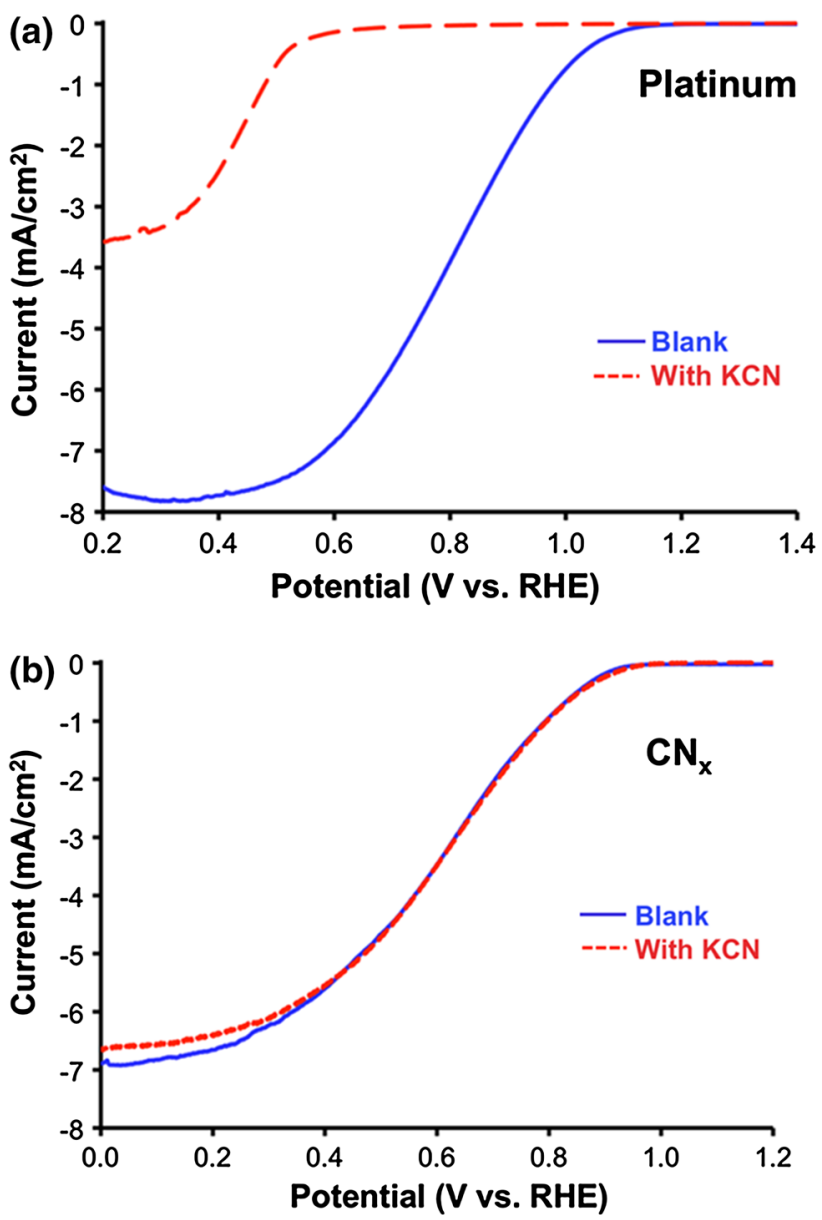

Fig. $11 \mathrm{RDE}$ scans of a $\mathrm{Pt} / \mathrm{VC}$ and $\mathbf{b} \mathrm{CN}_{\mathrm{x}}$ in phosphate buffer solution (blue) and phosphate buffer $+10 \mathrm{mMol} \mathrm{KCN} \mathrm{(red).} \mathrm{Scans}$ were performed at $1,000 \mathrm{rpm}$ in $\mathrm{O}_{2}$-saturated solution

density are identical in the scans run with and without KCN (Fig. 11b). This result provides a strong evidence that in the $\mathrm{CN}_{\mathrm{x}}$ materials, which are prepared by acetonitrile decomposition over a metal-doped oxide surface, metalcentered active sites are not present [36].

\section{$7 \mathrm{FeNC}$ and $\mathrm{CN}_{\mathrm{x}}$ : Differences and Similarities}

\subsection{Structural, Compositional and Surface Comparisons: Nature and Role of $\mathrm{Fe}$}

In the next phase of our studies, we focused some of our efforts in understanding the differences and similarities between two classes of carbon-based materials that are used as ORR catalysts, FeNC and $\mathrm{CN}_{\mathrm{x}}$. FeNC catalysts were prepared by adapting a procedure described by Dodelet and co-workers [14] where phenonthroline was used as a pore filler for Black Pearls, followed by wet impregnation with an iron precursor, such as Fe-acetate. After ball 
milling, the resulting materials were heat treated first in an inert, then in $\mathrm{NH}_{3} \cdot \mathrm{CN}_{\mathrm{x}}$ catalysts were prepared pyrolizing $\mathrm{CH}_{3} \mathrm{CN}$ over growth substrates such as a Fe-doped oxide support $(\mathrm{MgO})$, followed by acid washing. These two catalysts showed major differences as well as some similarities.

$\mathrm{CN}_{\mathrm{x}}$ catalysts were highly graphitic, showing a welldefined stacked cup structure and with Fe particles clearly visible encased in some of the "cup"s (Fig. 12). FeNC catalysts were mostly amorphous, with metallic Fe particles being visible on the surface [38].

The effect of acid washing was markedly different for the two catalysts. While $\mathrm{CN}_{\mathrm{x}}$ showed a dramatic improvement in activity after acid washing, FeNC, exhibited a noticeable decrease in its activity. This trend is a first evidence of the inherent differences in the catalytic active sites of the catalysts. Acid washing possibly leaches away some of the $\mathrm{Fe}$ from the active $\mathrm{Fe}-\mathrm{N}_{\mathrm{x}}$ sites in $\mathrm{FeNC}$, leading to an activity loss, while in the case of $\mathrm{CN}_{\mathrm{x}}$, the effect of acid washing is to eliminate the exposed iron species from the catalyst surface, along with the oxide support. Table 1 shows a comparison of the half-wave potentials for $\mathrm{FeNC}$ and $\mathrm{CN}_{\mathrm{x}}$ before and after washing.
When these two catalysts were immersed in $1 \mathrm{M} \mathrm{HCl}$ for extended periods of time, a further difference emerged. $77 \%$ of the iron in $\mathrm{CN}_{\mathrm{x}}$ leached out within the first hour, indicating that a significant amount of $\mathrm{Fe}$ in these samples was exposed after the pyrolysis step and that it could be leached out easily. The total concentration of iron leached out from $\mathrm{CN}_{\mathrm{x}}$ was also much greater than that of $\mathrm{FeNC}$, (77\% for $\mathrm{CN}_{\mathrm{x}}$ versus $24 \%$ for $\mathrm{FeNC}$ after the first hour). Another important observation was that, in the case of $\mathrm{CN}_{\mathrm{x}}$, most acid leaching took place within the first $1 \mathrm{~h}$ of being immersed in the acid solution, and there was little change in iron content after that whereas FeNC continued losing $\mathrm{Fe}$ with increased immersion time.

Table 1 Half-wave potentials of FeNC and $\mathrm{CN}_{\mathrm{x}}$ catalysts before and after washing

\begin{tabular}{ll}
\hline Sample & Half-wave potential (V vs NHE) \\
\hline FeNC-unwashed & 0.74 \\
FeNC-washed & 0.69 \\
$\mathrm{CN}_{\mathrm{x}}$-unwashed & 0.40 \\
$\mathrm{CN}_{\mathrm{x}}$-washed & 0.65 \\
\hline
\end{tabular}

Fig. 12 TEM images of a $\mathrm{CN}_{\mathrm{x}}$ (washed) and b FeNC (unwashed)
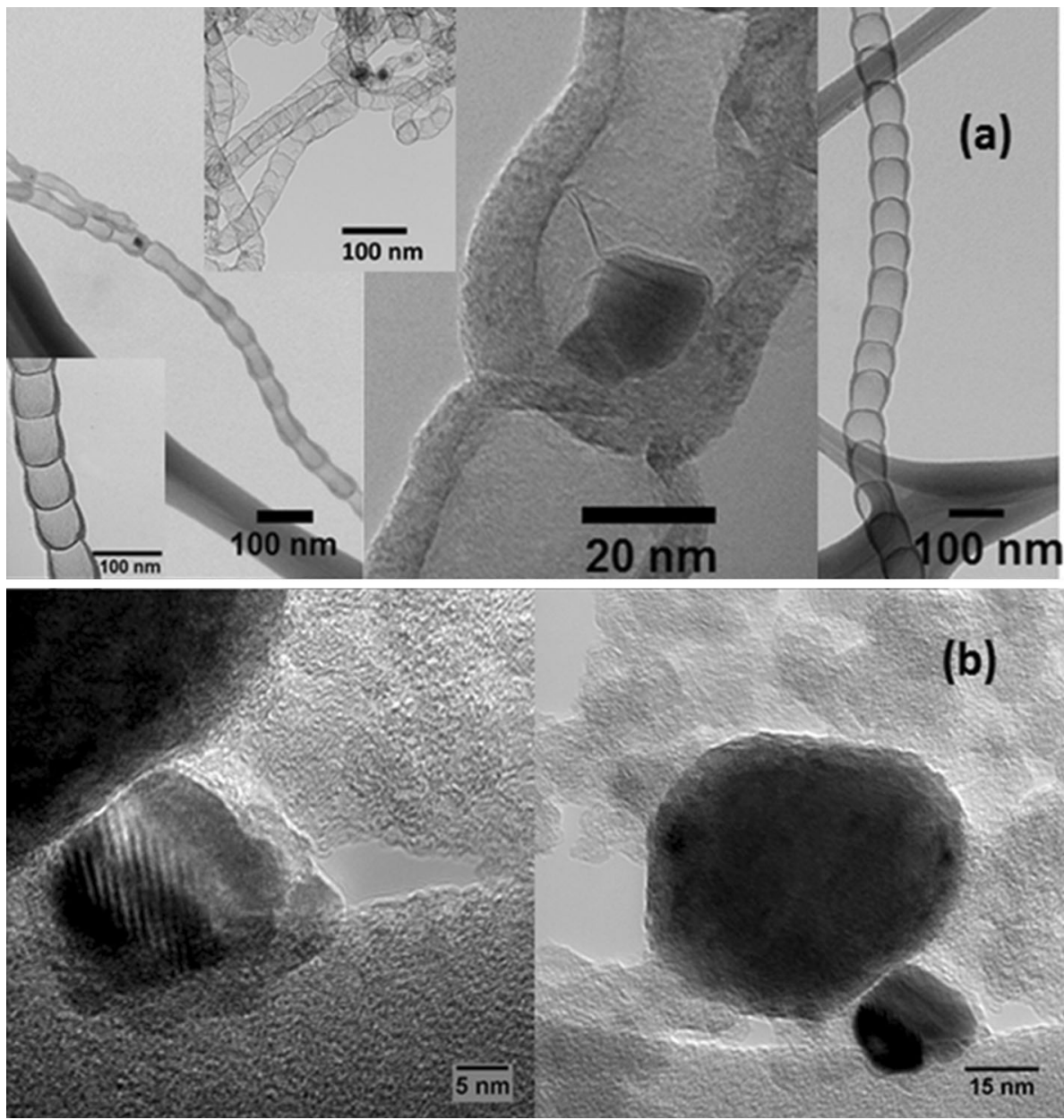


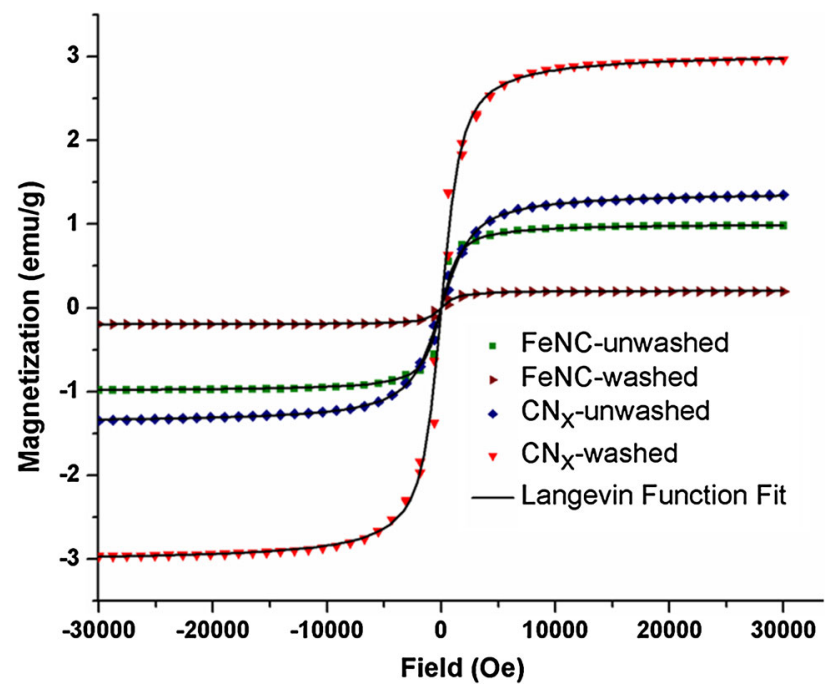

Fig. 13 Effect of acid-washing on magnetization as a function of field at $300 \mathrm{~K}$ for $\mathrm{CN}_{\mathrm{x}}$ and $\mathrm{FeNC}$ catalysts

The magnetization of these two materials was also compared using a superconducting quantum interference device (SQUID) magnetometer. Figure 13 shows the magnetization as a function of field at $300 \mathrm{~K}$ for $\mathrm{CN}_{\mathrm{x}}$ and $\mathrm{FeNC}$ (washed and unwashed). The data suggest a superparamagnetic behavior for all samples as evident from the negligible hysteresis in the curves. The acid-washing step led to an increase in the saturation magnetization for $\mathrm{CN}_{\mathrm{x}}$ sample while it showed the opposite effect for FeNC catalyst [38].

The effect of acid washing was further examined by extended X-ray absorption spectroscopy (EXAFS). A comparison of the FT magnitudes of the Fe-K edge for the catalysts and the standards is shown in Fig. 14 (values are uncorrected). $\mathrm{CN}_{\mathrm{x}}$ shows major differences due to washing. $\mathrm{CN}_{\mathrm{x}}$-unwashed has $\mathrm{Fe}$ in $2+$ oxidation state due to oxidation of the exposed iron species upon contact with air after pyrolysis. After acid-washing, all of the oxidized Fe species is leached away, and what is left behind is mostly carbidic or metallic Fe encased in the carbon nanostructures. The two spectra for FeNC, on the other hand, are very similar, with features that could correspond to $\mathrm{Fe}-\mathrm{Fe}$ and $\mathrm{Fe}-\mathrm{C}_{\mathrm{x}}$ or $\mathrm{Fe}-\mathrm{N}_{\mathrm{x}}$ bonds.

XPS spectra of the $\mathrm{CN}_{\mathrm{x}}$ and $\mathrm{FeNC}$ catalysts in the $\mathrm{N} 1 \mathrm{~s}$ region revealed further differences in the distribution of their $\mathrm{N}$ species (Fig. 15). The $\mathrm{N} 1 \mathrm{~s}$ region was deconvoluted into three different nitrogen species, identified as pyridinic $\mathrm{N}$ (398.0-398.9 eV) [11, 39], quaternary-N $(401-402 \mathrm{eV})$ [39, $40]$, and oxygenated pyridinic- $\mathrm{N}$ groups $\left(\mathrm{N}^{+}-\mathrm{O}^{-}\right)$at binding
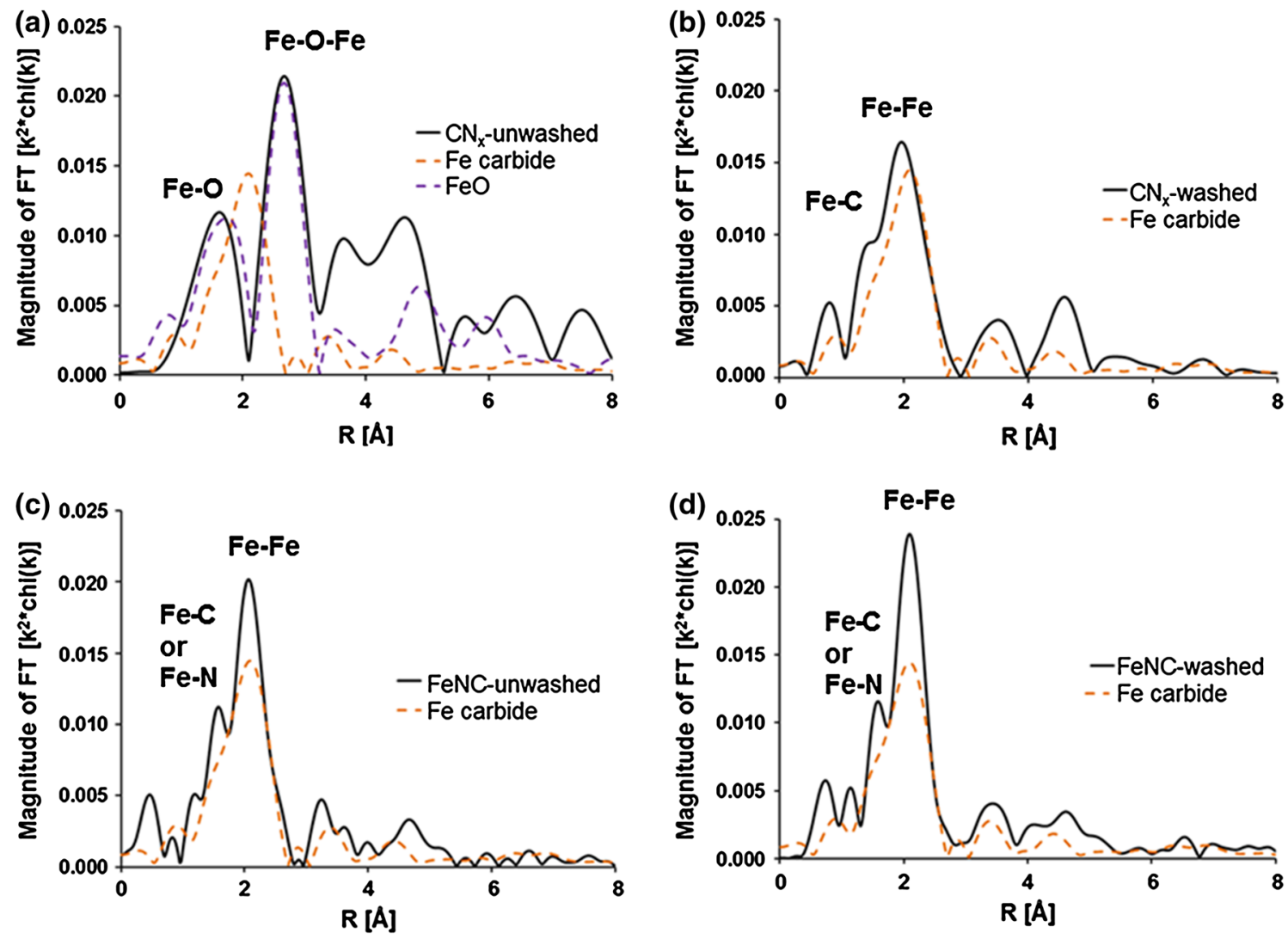

Fig. 14 FT magnitudes of Fe-K edge of a $\mathrm{CN}_{\mathrm{x}}$-unwashed, b $\mathrm{CN}_{\mathrm{x}}$-washed, c FeNC-unwashed, d FeNC-washed. Reference spectra for Fe carbide, $\mathrm{FeO}$, and $\mathrm{Fe}$ foil are included for comparison 


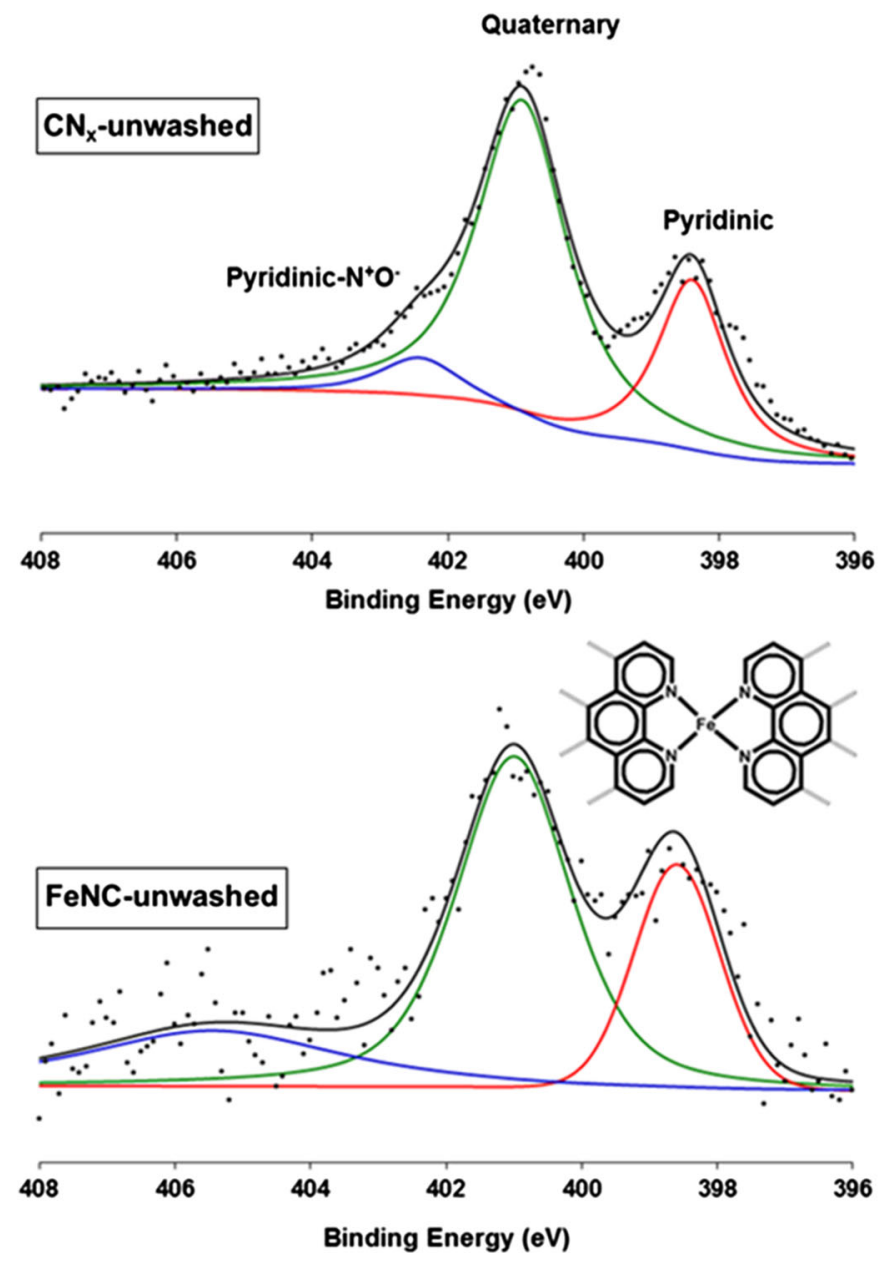

Fig. $15 \mathrm{~N} 1 \mathrm{~s}$ XPS spectra of $\mathrm{CN}_{\mathrm{x}}$ and FeNC before and after washing

energies higher than $402 \mathrm{eV}[16,19,41]$. The fraction of $\mathrm{N}$ in pyridinic form was the same in $\mathrm{CN}_{\mathrm{x}}$ catalyst before and after washing, suggesting that washing, which leaches out the oxide support and the exposed metal, does not affect the nitrogen species.

In the case of FeNC, there was a significant increase in the relative pyridinic-N content after washing. A possible explanation for this increase could be that Fe-species that were coordinated to edge-nitrogen species on two graphite planes were washed away, leaving behind more exposed edge-nitrogen and subsequently increasing the percentage of pyridinic nitrogen in FeNC (Fig. 17, inset).

\subsection{Stability Comparisons}

The long term stability and activity of $\mathrm{CN}_{\mathrm{x}}$ and FeNC catalysts were also compared in both half-cell and a single PEM fuel cell [38]. In these tests the active forms of the two catalysts, FeNC-unwashed and $\mathrm{CN}_{\mathrm{x}}$-washed were used. The accelerated durability tests showed that, over FeNC, there was a continued deterioration of performance

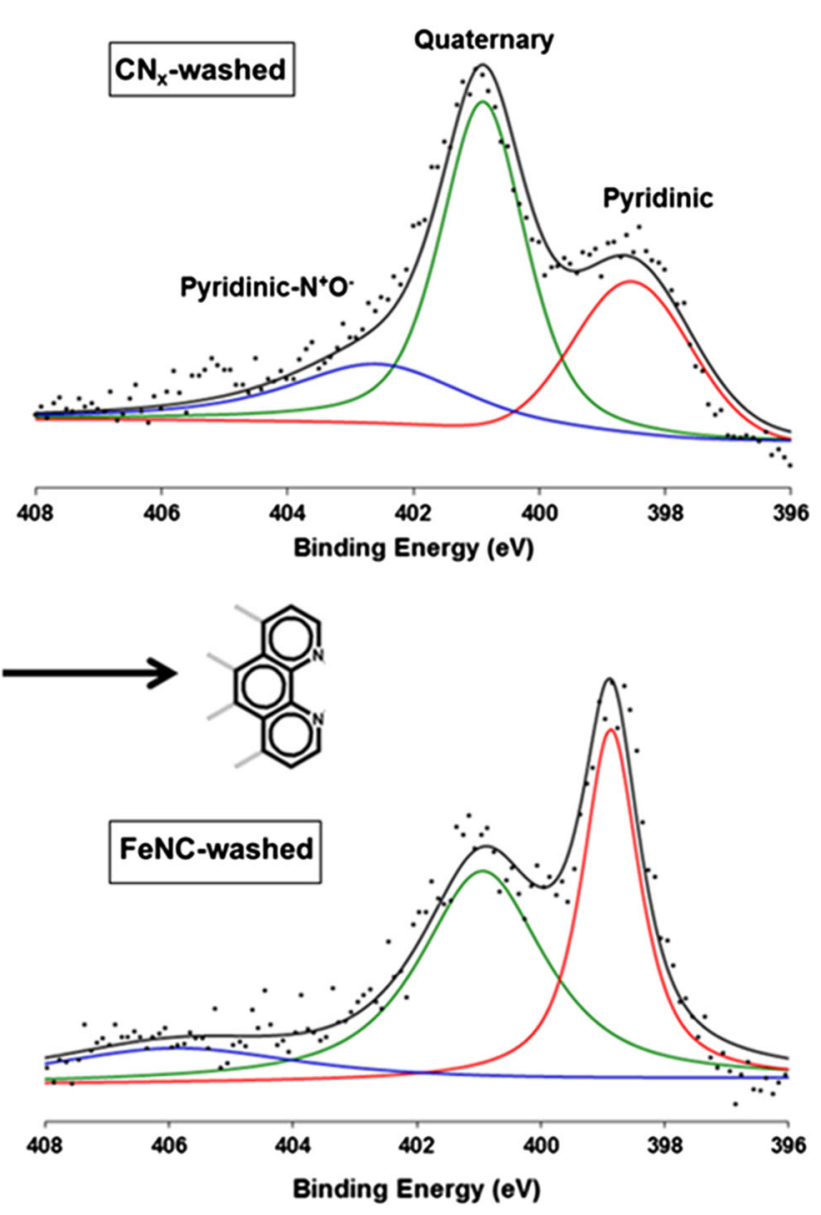

with repeated cycles whereas $\mathrm{CN}_{\mathrm{x}}$ demonstrated the highest activity loss during the first 100 cycles, after which, it reached a pseudo-steady state, as there was no significant activity loss between 100, 500 and 1,000 cycles. As we have reported earlier [30], $\mathrm{CN}_{\mathrm{x}}$ materials do not undergo carbon corrosion as severely as some other carbon supports, such as $\mathrm{VC}$, and this could be one of the factors responsible for its prolonged stability. Stability tests in a PEM fuel cell showed that the initial activity of the FeNC catalyst was significantly higher than that of the $\mathrm{CN}_{\mathrm{x}}$ catalysts, but after the 100-h voltage hold at $0.5 \mathrm{~V}$, their performances became much more similar.

\subsection{Use of $\mathrm{H}_{2} \mathrm{~S}$ Poisoning as a Probe}

In spite of well-established differences, the question of the active site and the role of the metal in these two classes of catalysts continues to linger. Additional studies were performed to probe the active site in both materials using $\mathrm{H}_{2} \mathrm{~S}$, a well-known poison [42, 43]. Activity loss in iron-based catalysts has been attributed to sulfur for many well-known 

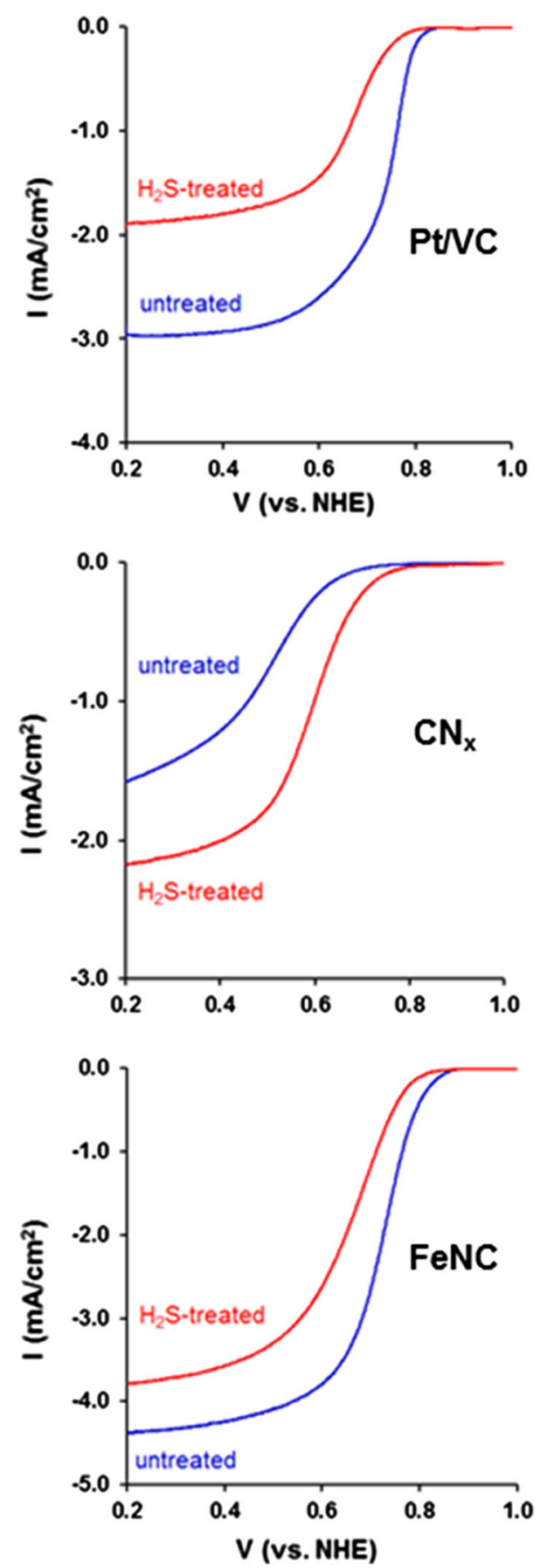

Fig. 16 ORR activity measurements by RDE in $0.5 \mathrm{M} \mathrm{H}_{2} \mathrm{SO}_{4}$ for $\mathrm{Pt} /$ $\mathrm{VC}, \mathrm{CN}_{\mathrm{x}}$ and $\mathrm{FeNC}$

reactions such as Fisher-Tropsch, water-gas shift, ammonia synthesis, ammonia decomposition and iron carburization [44-47]. Furthermore, hydrogen sulfide is known to readily bind to the oxygen adsorption iron site in heme at $37{ }^{\circ} \mathrm{C}$ [48]. Hence, the conjecture of an iron-based catalytic site would only be proved if the catalysts exhibited a similar deactivation when exposed to hydrogen sulfide. Figure 16 compares the effect of $\mathrm{H}_{2} \mathrm{~S}$ exposure on ORR activity for $\mathrm{Pt} / \mathrm{VC}, \mathrm{FeNC}$ and $\mathrm{CN}_{\mathrm{x}}$ catalysts as measured by RDE. Both Pt/VC and FeNC catalysts that were exposed to $\mathrm{H}_{2} \mathrm{~S}$ showed a decrease in activity, as manifested by the lower onset potential and the lower limiting current as compared to untreated counterparts. $\mathrm{CN}_{\mathrm{x}}$ treated with $\mathrm{H}_{2} \mathrm{~S}$, however, was observed to have an increase in activity as compared to untreated $\mathrm{CN}_{\mathrm{x}}$, indicating that $\mathrm{CN}_{\mathrm{x}}$ was not at all poisoned by exposure to sulfur. On the contrary, its activity improved. Although it is not clear at this point why such an improvement took place, it is conceivable that sulfur may be providing additional heteroatom substitutions in the carbon matrix and, hence changing its electron donation and/or oxygen adsorption characteristics.

$\mathrm{N} 1 \mathrm{~s}$ regions of the X-ray photoelectron spectra for untreated and $\mathrm{H}_{2} \mathrm{~S}$-treated $\mathrm{CN}_{\mathrm{x}}$ and $\mathrm{FeNC}$ catalysts show that following sulfur exposure, the contribution from pyridinic $\mathrm{N}$ species increased for $\mathrm{CN}_{\mathrm{x}}$ while it decreased for FeNC [42, 43]. One possible explanation for this increase in $\mathrm{CN}_{\mathrm{x}}$ is the conversion of pyridinic $\mathrm{N}^{+} \mathrm{O}^{-}$sites back to pyridinic $\mathrm{N}$ sites by removal of oxygen with $\mathrm{H}_{2} \mathrm{~S}$. The decrease in the relative intensity of $\mathrm{N}^{+} \mathrm{O}^{-}$sites supports this possibility. It is also possible that the increase observed in ORR activity may also be related to this increase in pyridinic $\mathrm{N}$ density on the surface. It is not clear if the decrease in pyridinic $\mathrm{N}$ contribution over the FeNC catalysts may partially account for the decrease in ORR activity, especially if both $\mathrm{Fe}$ and $\mathrm{C}-\mathrm{N}$ sites are contributing to the activity. It is, however, more likely that the major cause of the activity of loss is the binding of sulfur to Fe sites as shown by the XAS studies, which are summarized below.

XAS experiments were performed in order to determine the changes in the phases as well as those in the local bonding environment of iron in the untreated and $\mathrm{H}_{2} \mathrm{~S}$-treated $\mathrm{CN}_{\mathrm{x}}$ and FeNC catalysts (Fig. 17). The XANES spectra for untreated and $\mathrm{H}_{2} \mathrm{~S}$-treated $\mathrm{CN}_{\mathrm{x}}$ catalysts (Fig. 17a), were identical indicating that the local Fe structure is unchanged by $\mathrm{H}_{2} \mathrm{~S}$ treatment. XANES spectra for $\mathrm{CN}_{\mathrm{x}}$ appeared to strongly resemble iron in the metallic or carbidic phases. The Fourier transform obtained at the $\mathrm{Fe} \mathrm{K}$ edge and $k^{2}$ weighted EXAFS (Fig. 17b) displayed a nearly identical local bonding environment for untreated and $\mathrm{H}_{2} \mathrm{~S}$ treated $\mathrm{CN}_{\mathrm{x}}$. Since TEM images have revealed iron to be encased in several graphitic layers in $\mathrm{CN}_{\mathrm{x}}$, the absence of any change in the iron phase between untreated and $\mathrm{H}_{2} \mathrm{~S}$-treated $\mathrm{CN}_{\mathrm{x}}$ is expected, considering that iron would not be affected by a chemical treatment when protected by sheets of carbon [42].

A similar comparison for FeNC showed a clear interaction of sulfur with the Fe sites (Fig. 17c, d). Spectra for $\mathrm{FeS}$ are also included in these figures as reference. As seen in the XANES spectra (Fig. 17c), the differences in preedge energies are evident in the $\mathrm{H}_{2} \mathrm{~S}$-treated and sulfur-free catalysts. While sulfur-treated sample has an identical preedge feature to iron(II) sulfide, indicating a +2 oxidation 

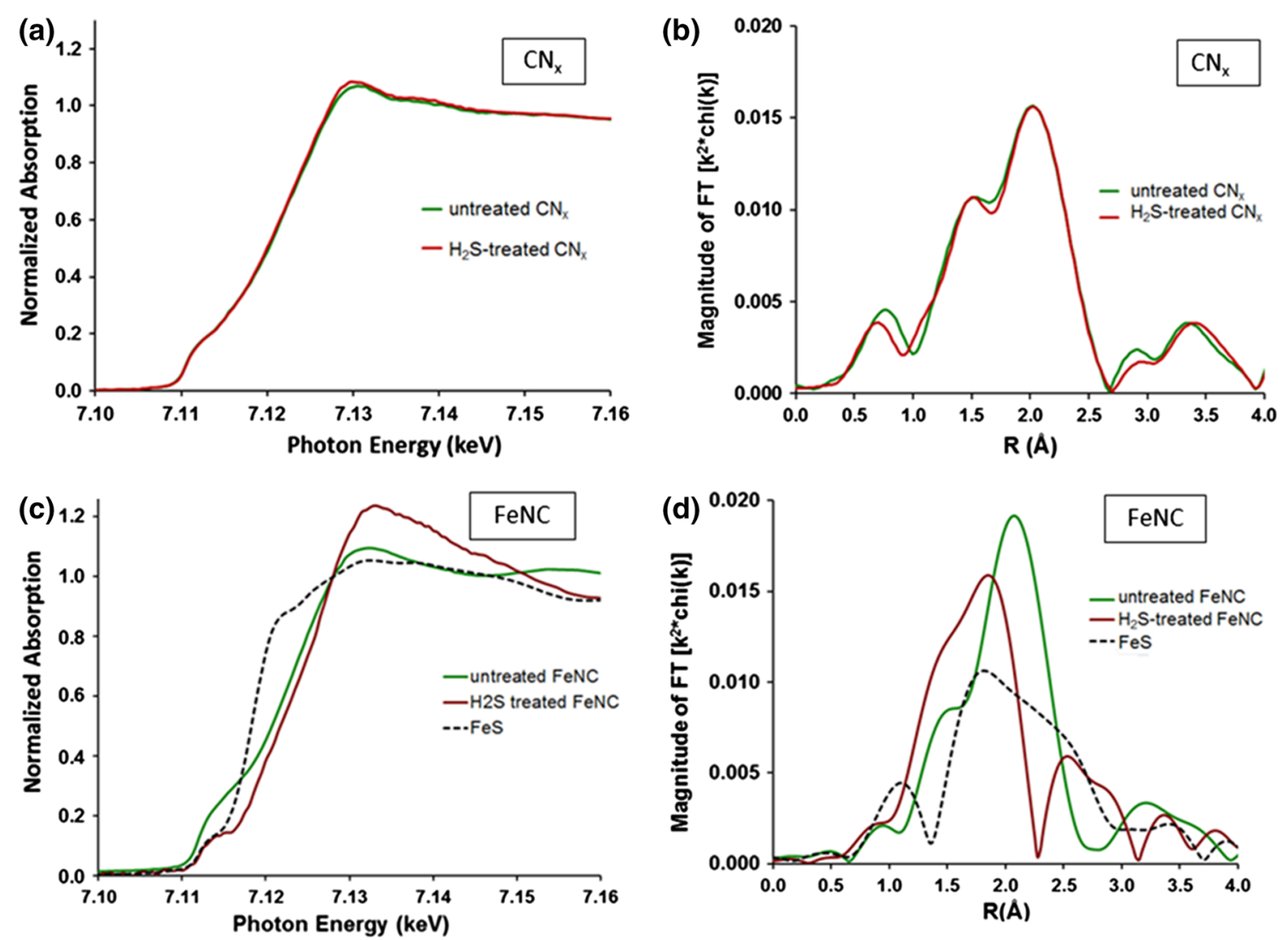

Fig. 17 Fe K-edge XAS spectra for $\mathrm{CN}_{\mathrm{x}}$ and FeNC before and after $\mathrm{H}_{2} \mathrm{~S}$ treatment a, c XANES, b, d EXAFS

state, it is significantly different from untreated FeNC which shows a more metallic character.

A comparison of the uncorrected FT magnitudes (Fig. 17d) showed contributions from $\mathrm{Fe}-\mathrm{S}$ at an uncorrected value of 1.9 Å corresponding to a bond length of $2.2 \AA$ from the EXAFS fit. This is indicative of iron-sulfur bond formation, which was also seen in XPS analysis of S 2p spectra [43]. The catalyst exposed to $\mathrm{H}_{2} \mathrm{~S}$ exhibits a very different coordination state from untreated sample, which shows a large peak for $\mathrm{Fe}-\mathrm{Fe}$ bond present in metal carbide, with a shoulder for $\mathrm{Fe}-\mathrm{C}$. This feature may have contributions from $\mathrm{Fe}-\mathrm{N}$ as well [49-51]. Both the XANES and EXAFS spectra imply that the sulfur treatment brought about a pronounced change in the oxidation state as well as local bonding environment of $\mathrm{Fe}$ in FeNC.

Thus, it was shown that hydrogen sulfide exposure to iron-containing $\mathrm{CN}_{\mathrm{x}}$ did not render it inactive whereas a strong deactivation effect was observed for FeNC catalyst. When combined with previous findings that demonstrated substantial ORR activity on a metal-free $\mathrm{CN}_{\mathrm{x}}$ catalyst, these observations point towards a metal-free ORR active site in $\mathrm{CN}_{\mathrm{x}}$ while the metal has a clear role to play in FeNC catalysts. The ORR activity of $\mathrm{N}$-doped graphene sheets which are prepared without any metal incorporation has recently been reported, providing additional support for our conclusions about the $\mathrm{CN}_{\mathrm{x}}$ catalysts [52].

\section{Conclusions}

These studies showed nitrogen-doped carbon nano-structures $\left(\mathrm{CN}_{\mathrm{x}}\right)$ to have substantial activity for ORR in acidic media. While they are not as active as Pt-based catalysts, they appear to be quite stable, with much higher resistance to carbon corrosion than other carbon supports, as well as much lower activity loss in accelerated half-cell and polarization measurements. They also have no activity for methanol oxidation and no activity loss in the presence of methanol, making them promising candidates for DMFCs.

These studies also answered many of the questions about the nature and the role of the metal that is used in the growth of these carbon nanostructures. Some of the questions stemmed from an ongoing debate about two classes of catalysts, often denoted in the literature as $\mathrm{FeNC}$ and $\mathrm{CN}_{\mathrm{x}}$, whether they were different materials or the same materials with different names. An important outcome of these studies was the conclusion that $\mathrm{FeNC}$ and $\mathrm{CN}_{\mathrm{x}}$ are quite different materials. The $\mathrm{CN}_{\mathrm{x}}$ catalysts reported in our studies are prepared by pyrolyzing a carbon-nitrogen source, such as acetonitrile, over a growth medium. Most often, the support is an oxide (alumina, silica, magnesia), either used alone or doped with a transition metal ( $\mathrm{Fe}$ or $\mathrm{Co}$ ). These materials then go through a washing step with a strong acid or a base. 
Following this step, the resulting materials are graphitic carbon with different nano-geometries and high nitrogen content. Any transition metal left behind cannot be detected by surface analysis techniques, such as XPS. The iron species left behind in catalysts grown on Fe-doped supports were characterized by TEM, Mössbauer, and XAFS studies which showed $\mathrm{Fe}$ to be primarily encased in carbon, exhibiting mostly a cementite-type carbide and metal phases. These species do not interact with $\mathrm{CO}, \mathrm{H}_{2} \mathrm{~S}$ or cyanide.

FeNC catalysts, on the other hand, are often prepared by supporting a macrocycle or an alcoxide on a carbon support and they do have a metal center. Some of these materials go through pyrolysis in an inert or nitrogen-containing environment, but there is never a washing step in their preparation to leach out the metal. It is expected that a metal center that was part of the starting precursor still remains in these materials. Although its exact nature may not yet be fully elucidated, it is clear that the Fe center can bind sulfur and be poisoned upon exposure to $\mathrm{H}_{2} \mathrm{~S}$.

There remain many questions about the nature of active sites in $\mathrm{FeNC}$ and $\mathrm{CN}_{\mathrm{x}}$ catalysts. But it appears that the ORR activity in these materials stem from different active sites, although presence of more than one type of active site on each class of materials cannot be ruled out.

Acknowledgments We gratefully acknowledge the financial support by the U. S. Department of Energy, Office of Science, Office of Basic Energy Sciences, under Contract No. DE-FG02-07ER15896. Portions of this work were performed at the DuPont-NorthwesternDow Collaborative Access Team (DND-CAT) located at Sector 5 of the Advanced Photon Source (APS). DND-CAT is supported by E.I. DuPont de Nemours \& Co., The Dow Chemical Company and Northwestern University. Use of the APS, an Office of Science User Facility operated for the U.S. Department of Energy (DOE) Office of Science by Argonne National Laboratory, was supported by the U.S. DOE under Contract No. DE-AC02-06CH11357. We would also like to thank our collaborators Dr. Jeffrey Miller (Argonne National Laboratories) and Dr. Jean-Marc Millet (Institut de Recherche sur la Catalyse et l'Environnement de Lyon) for their invaluable help with XAS and Mossbauer spectroscopy studies, respectively. We also thank Dr. Aravind Asthagiri and Dr. Christopher Hadad of the Ohio State University for the valuable insight they provided through molecular modeling studies. Finally, we would like to acknowledge many former members of the Heterogeneous Catalysis Research Group (HCRG) at Ohio State, especially Dr. Paul Matter, Dr. Elizabeth Biddinger, Dr. Dieter von Deak, Dr. Juan Tian and Dr. Deepika Singh, who conducted most of the studies summarized in this overview.

\section{References}

1. Matter PH, Biddinger EJ, Ozkan US (2007) Non-precious metal oxygen reduction catalysts for PEM fuel cells. In: Spivey JJ (ed) Catalysis. The Royal Society of Chemistry, Cambridge

2. Gasteiger HA, Markovic NM (2009) Science 324:48

3. Singh D, King JC, Ozkan US (2013) Modified carbon materials as $\mathrm{O}_{2}$ reduction reaction electrocatalysts in acid PEM fuel cells.
In: Chen Z, Dodelet JP, Zhang J (eds) Non-noble metal fuel cell catalysts. Wiley, Weinheim, p 119

4. Jaouen F, Herranz J, Lefevre M, Dodelet J-P, Kramm UI, Herrmann I, Bogdanoff P, Maruyama J, Nagaoka T, Garsuch A, Dahn JR, Olson TS, Pylypenko S, Atanassov P, Ustinov EA (2009) ACS Appl Mater Interfaces 1:1623

5. Jasinski R (1964) Nature 201:1212

6. Jasinski R (1965) J Electrochem Soc 112:526

7. Scherson D, Tanaka AA, Gupta SL, Tryk D, Fierro C, Holze Z, Yeager EB (1986) Electrochim Acta 31:1247

8. Van Veen JAR, van Baar JF, Kroese KJ (1981) Chem Soc Faraday Trans I. 77:2827

9. Fournier J, Lalande G, Cote R, Guay D, Dodelet JP (1997) J Electrochem Soc 144:218

10. Faubert G, Côté R, Dodelet JP, Lefèvre M, Bertrand P (1999) Electrochim Acta 44:2589

11. Jaouen F, Marcotte S, Dodelet J-P, Lindbergh G (2003) J Phys Chem B 107:1376

12. Lalande G, Cote R, Guay D, Dodelet JP, Weng LT, Bertrand P (1997) Electrochim Acta 42:1379

13. Lefevre M, Dodelet JP, Bertrand P (2002) J Phys Chem B 106:8705

14. Lefevre M, Proietti E, Jaouen F, Dodelet J-P (2009) Science 324:71

15. Matter PH, Wang E, Ozkan US (2006) J Catal 243:395

16. Matter PH, Zhang L, Ozkan US (2006) J Catal 239:83

17. Matter PH, Ozkan US (2006) Catal Lett 109:115

18. Matter PH, Wang E, Arias M, Biddinger EJ, Ozkan US (2006) J Phys Chem B 110:18374

19. Biddinger EJ, Ozkan US (2010) J Phys Chem C 114:15306

20. Matter PH, Wang E, Millet J-MM, Ozkan US (2007) J Phys Chem C 111:1444

21. Matter PH, Wang E, Arias M, Biddinger EJ, Ozkan US (2007) J Mol Catal 264:73

22. Singh D, Soykal II, Tian J, Von Deak D, King JC, Miller JT, Ozkan US (2013) J Catal 304:100

23. Arico AS, Srinivasan S, Antonucci V (2001) Fuel Cells 1:133

24. Dillon R, Srinivasan S, Arico AS, Antonucci V (2004) J Power Sources 127:112

25. Gilman S, Chu D (2003) Methanol effects on the $\mathrm{O}_{2}$ reduction reaction. In: Vielstich W, Gasteiger HA, Lamm A (eds) Handbook of fuel cells: fundamentals, technology and applications. Wiley, Weinheim

26. Biddinger EJ, Ozkan US (2007) Top Catal 46:339

27. Li L, Xing Y (2006) J Electrochem Soc 153:A1823

28. Li L, Xing Y (2008) J Power Sources 178:75

29. Kangasniemi KH, Condit DA, Jarvi TD (2004) J Electrochem Soc 151:E125

30. von Deak D, Biddinger EJ, Ozkan US (2011) J Appl Electrochem 41:757

31. Cruz-Silva E, Cullen DA, Gu L, Romo-Herrera JM, MunozSandoval E, Lopez-Urias F, Sumpter BG, Meunier V, Charlier J-C, Smith DJ, Terrones H, Terrones M (2008) ACS Nano 2:441

32. von Deak D, Biddinger EJ, Luthman KA, Ozkan US (2010) Carbon 48:3637

33. Benissad-Aissani F, Ait-Amar H, Schouler M-C, Gadelle P (2004) Carbon 42:2163

34. Bao X, von Deak D, Biddinger EJ, Ozkan US, Hadad CM (2010) Chem Commun 46:8621

35. Biddinger EJ, Knapke DS, von Deak D, Ozkan US (2010) Appl Catal B 96:72

36. von Deak D, Singh D, King JC, Ozkan US (2012) Appl Catal B 113-114:126

37. Thorum MS, Hankett JM, Gewirth AA (2011) J Phys Chem Lett 2:295 
38. Singh D, Tian J, Mamtani K, King J, Miller JT, Ozkan US (2014) J Catal 317:30

39. Pels JR, Kapteijn F, Moulijn JA, Zhu Q, Thomas KM (1995) Carbon 33:1641

40. Kapteijn F, Moulijn JA, Matzner S, Boehm H-P (1999) Carbon $37: 1143$

41. Biddinger EJ, von Deak D, Ozkan US (2009) Top Catal 52:1566

42. von Deak D, Singh D, Biddinger EJ, King JC, Bayram B, Miller JT, Ozkan US (2012) J Catal 285:145

43. Singh D, Mamtani K, Bruening CR, Miller JT, Ozkan US (2014) ACS Catal 4:3454

44. Oudar J (1980) Catal Rev 22:171

45. Arabczyk W, Moszynski D, Narkiewicz U, Pelka R, Podsiadly M (2007) Catal Today 124:43
46. Garsany Y, Baturina OA, Swider-Lyons KE (2009) J Electrochem Soc 156:B848

47. Zhang L, Millet JMM, Ozkan US (2009) J Mol Catal A 309:63

48. Alberts B, Johnson A, Lewis J, Raff M, Roberts K, Walter P (2002) Molecular biology of the cell, 4th edn. New York, Garland science

49. Liu S-H, Wu J-R, Pan C-J, Hwang B-J (2014) J Power Sources 250:279

50. Bron M, Radnik J, Fieber-Erdmann M, Bogdanoff P, Fiechter S (2002) J Electroanal Chem 535:113

51. Tsai C-W, Chen HM, Liu R-S, Asakura K, Zhang L, Zhang J, Lo M-Y, Peng Y-M (2011) Electrochim Acta 56:8734

52. Zhang L, Niu J, Dai L, Xia Z (2012) Langmuir 28:7542 